Jurnal of Education Technologi and Innovation (JETI)

Volume 01 No 2 Desember 2018

doi. https://doi.org/10.31537/jeti.v1i2

p-ISSN : 262-2080

e-ISSN: 2621-2137

\title{
KEARIFAN LOKAL BUDAYA MINANG "DIMA BUMI DIPIJAK, DISITU LANGIT DIJUNJUNG” DALAM KONTEKS ETNOPEDAGOGI \\ Kasus Perantau Minang di Kota Surabaya
}

\author{
Minang Culture Local Wisdom "dima bumi dipijak, disitu langit dijunjung" in the Context of \\ Etnopedagogy: \\ The Case of the Minang Diaspora in the City of Surabaya \\ Yosi Trisa $^{1)}$, Agus Suprijono" ${ }^{1)}$, M. Jacky ${ }^{1)}$ \\ Postgraduate Social Sciences Education (PIPS) \\ Surabaya State University (UNESA) \\ yosi.trisa@yahoo.com
}

\begin{abstract}
Abstrak:
Artikel ini berbasis penelitian kualitatif dengan pendekatan etnografi yang dilakukan selama tiga bulan (Agustus-Oktober 2018) pada para perantau Minangkabau di kota Surabaya. Tujuan penelitian adalah untuk memhami bagaimana penerapan nilai-nilai Kearifan Lokal Budaya Minang “dima bumi dipijak, disitu langit dijunjuang” dalam Konteks Etnopedagogi oleh Perantau Minang di Kota Surabaya. Hasil penelitian menunjukkan bahwa terdapat paling tidak lima nilainilai budaya Minangkabau yang sangat penting untuk dimasukkan sebagai bagian dari materi etnopedagogi. Kelima nilai budaya tersebut adalah: 1) Saling menghormati (toleransi), saling menghargai, tenggang rasa, dan inklusif (“Dima bumi dipijak, disitu langik dijunjuang”); 2) Hidup mandiri, ("Karatau madang di hulu, Babuah babungo balun; Marantau Bujang dahulu, Di rumah baguno balun"); 3) Pantang menyerah ("Baraja ka na manang, mancontoh ka nan sudah" dan "Takuruang nak dilua, taimpik nak diateh"); 4) Nilai-nilai agama ("Adat basandi syarak, syarak basandi kitabullah"), dan 5) Mempertahankan bahasa lokal. Sebagai konsekuensi dari hidup merantau, peran dan fungsi mamak tidak dapat dilaksanakan sepenuhnya sehingga pihak orangtua (ayah/bapak) yang mengambil alih.
\end{abstract}

Kata kunci: etnopedagogi, kearifan lokal, budaya Minangkabau.

\begin{abstract}
:
This article is based on qualitative research with an ethnographic approach carried out for three months (August-October 2018) to Minangkabau nomads in the city of Surabaya. The aim of the study was to understand how the application of the Minang Culture Local Wisdom values "dima bumi dipijak, disitu langit dijunjuang" in the Context of Ethnopedagogy by Perantau Minang in Surabaya City. The results of the study show that there are at least five Minangkabau cultural values that are very important to be included as part of the ethopathic material. The five cultural values are: 1) Mutual respect (tolerance), mutual respect, tolerance, and inclusiveness ("Dima bumi dipijak, disitu langit dijunjuang "); 2) Live independently, ("Karatau madang di hulu,
\end{abstract}


Babuah babungo balun; Marantau Bujang dahulu, Di rumah baguno balun”); 3) Never give up ("Baraja ka na manang, mancontoh ka nan sudah" dan "Takuruang nak dilua, taimpik nak diateh”); 4) Religious values ("Adat basandi syarak, syarak basandi kitabullah"), and 5) Maintain local language. As a consequence of living abroad, the role and function of mamak cannot be fully implemented so that the parents (father / father) take over.

Keywords: ethnopedagogy, local wisdom, Minangkabau culture.

\section{PENDAHULUAN}

\section{Latar Belakang Masalah}

Setiap masyarakat di kebudayaan mana pun memiliki falsafah hidup sebagai kearifan lokal yang menjadi acuan dalam berpikir, bertindak dan berperilaku dalam kehidupan sosialnya. Pada umumnya falsafah hidup ini berupa ungkapan-ungkapan simbolik yang memiliki makna sesuai dengan konteksnya. Falsafah hidup merupakan bagian dari kebudayaan secara keseluruhan. Oleh karena itu, falsafah hidup tidak terlepas dari konsep kebudayaan yang pada hakekatnya merupakan konsep semiotik sekaligus merupakan jaringan-jaringan makna, dimana manusia yang membuat jaringan-jaringan itu tergantung (Geertz, 1973:5).

Masyarakat Minangkabau di Sumatera Barat telah dikenal menganut system kekerabatan menurut garis keturnuan ibu (matrilenial kinship system). Salah satu konsekuensi kulturalnya adalah mewajibkan para kaum laki-laki untuk merantau biasanya dimualai sejak setelah lulus pendidikan tingkat SLTP atau SLTA mereka sudah mulai berangkat ke kota lain. Bagi laki-laki Minangkabau merantau merupakan cara paling ideal untuk meraih kematangan dan kesuksesan. Dengan merantau tidak hanya untuk memperoleh kekayaan dan pengetahuan melainkan juga untuk meraih prestise serta kebanggaan pribadi (Hastuti, 2015:3). Merantau juga memiliki makna sebagai ajang pembuktian diri seseorang. Dengan berhasil merantau, maka seseorang berharap dapat dianggap mandiri oleh orang-orang di kampungnya dan menjadi prestise tersendiri bagi dirinya (Marta, 2014:34).

Sebagai perantau, mereka harus memegang teguh dan mewujudkan makna nilai-nilai budaya yang berlaku pada semua orang Minangkabau, yaitu "dima bumi dipijak, disitu langik 
dijunjuang” (di mana bumi dipijak, di situ langit dijunjung). Ungkapan ini merupakan mengangndung nilai-nilai sebagai etika sosial, khususnya bagi perantau Minangkabau dalam hal berpikir, berperilaku, dan bertindak yang harus ditaati. Kemana dan di mana pun orang Minangkabau merantau mereka harus menjalin interaksi dengan orang atau komunitas lain. Dalam proses interaksi ini mereka harus bisa dan mampu beradaptasi dalam arti menyesuaikan diri dengan kondisi lingkungan sosial setempat, yang mencakup adat-istiadat, tradisi-tradisi, kebiasaankebiasaan, serta etika-etika dalam pergaulan sosial lainnya. Menyesuaikan diri dalam arti harus pandai-pandai membawakan diri agar dalam proses interaksi itu dapat terbangun suatu kehidupan harmonis dan damai tanpa konflik.

Konsekuensi kultural lain dari system kekerabatan matrilineal (matrilineal kinship system), setiap kamanakan (anak-anak dari garis keturunan ibu) harus dibimbing oleh mamak (saudara lakilaki dari pihak ibu) terutama dalam hal pengasuhan, pendidikan, dan semua aspek kehidupan yang lain. Dengan demikian, pihak ayah hanya berfungsi dan berperan mengawasi anak-anak mereka. Demikian, seterusnya hal ini berlaku dan berlangsung secara tutun-temurun. Dalam budaya Minangkabau disebut: anak dipangku, kamanakan dibimbing (Amir: 2014; Amri: 2000; Thaher: 2006; Kato: 2005).

Berdasarkan uraian tersebut dua hal penting yang dihadapi oleh perantau Minangkabau di kota Surabaya yaitu proses adaptasi, dan peran mamak - yang digantikan oleh pihak ayah - dalam hal pengasuhan, bimbingan, serta pendidikan anak-anak mereka.

\section{Kajian Literatur}

\section{a. Pengertian Falsafah Budaya “dima bumi dipijak, disitu langik dijunjuang”.}

Masyarakat Minangkabau di Sumatera Barat merupakan satu-satunya masyarakat di Indonesia yang menganut system kekerabatan berdasarkan garis ibu (matrilineal kinship system), dan yang terbesar di dunia (Valentina, dan Putera, 2008:3; Rathina, 2016; Elfira, 2018:175). Konsekuensi kulturalnya adalah kewajiban bagi kaum laki-laki Minang merantau. Hampir tidak ada informasi bahwa perantau Minang gagal atau tidak berhasil dalam meningkatkan taraf hidupnya di rantau. Diantara factor-faktor yang mendukung keberhasilan orang Minang di rantau adalah teguhnya mereka melaksanakan atau menjalankan falsafah budaya "dima bumi dipijak, disitu langik dijunjuang” (Handoko dan Putri, 2017:151; Ardi, 2015:231). 
Falsafah budaya "dima bumi dipijak, disitu langik dijunjuang" biasanya dilanjutkan dengan pepatah" elok-elok manyubarang, jan sampai titian patah, -elok di rantau urang, jan sampai babuek salah" (berbuat baiklah di negeri orang jangan sampai berbuat salah). Tidak hanya sampai di situ, masih banyak lagi pepatah yang mengandung nilai budaya Minang lainnya yang semuanya bermakna sebagai etika sosial, oleh karenanya harus dipegang teguh dan dipatuhi dalam setiap kehidupan dan pergaulan sosial. Pepatah itu antara lain adalah: "baso-basi, malu jo sopan" dan "tenggang raso" (Demina, 2016:8) artinya selain memiliki sikap tenggang rasa juga sopan santun harus betul-betul dijaga. Jangan sampai terjadi perkataan atau perilaku yang dapat menyinggung atau menyakiti perasaan orang. Semua etika sosial yang ada sangat berkaitam erat dengan nilai-nilai ajaran Islam yang bersumber pada Al-qur'an dan Hadist, yaitu “adat basandi syarak, syarak basandi kitabullah" (Rahim, 2017:64-72).

Beberapa hasil penelitian sebelumnya menunjukkan bahwa dewasa ini mulai terjadi pergeseran dan perubahan tentang fungsi dan peran mamak terhadap kemenakannya yaitu tidak lagi sesuai dengan nilai budaya atau adat istiadat Minangkabau (Derby, 2017:12). Penelitian lain menyimpulkan hal senada bahwa seorang ayah atau laki-laki Minang yang awalnya lebih berperan dan berfungsi sebagai mamak dalam membimbing kemenakannya dari keluarga ibu telah mengalami pergeseran kini berperan dan bertanggung jawab terhadap keluarganya sendiri (Usmarni dan Rinaldi, 2014:48). Artinya peran dan fungsi mamak sudah diambil alih oleh ayah/bapak atau suami. Suatu penelitian lain yang menarik adalah perubahan pola komunikasi di antara anggota keluarga (khususnya antara anak dengan orangtua - ayah dan ibu, dan sebaliknya) sangat dipengaruhi oleh penggunaan media baru (internet, dan media sosial lainnya). Perubahan ini pada gilirannya mempengaruhi pula terhadap pola asuh yang dilakukan oleh kedua orangtuanya, artinya penanaman nilai-nilai kepada anak tidak lagi semata-mata dilakukan oleh kedua orangtua mereka, melainkan bergeser pada media baru tersebut (Yuniarti, dan Rahmadani, 2017:64). Dengan demikian, realisasi nilai-nilai falsafah budaya ini menjadi dasar bagi perwujudan prinsip-prinsip dasar etnopedagogi dalam keluarga.

\section{b. Teori Etnopedagogi.}

Meskipun kepribadian seseorang (anak) dapat dibentuk melalui pendidikan, namun proses pengasuhan serta pendidikan pada anak seharusnya tidak ditempatkan dalam ruang hampa sosialbudaya. Artinya, dalam proses tersebut dimensi sosial-budaya masyarakatnya berupa nilai-nilai 
yang masih berlaku harus diperhatikan oleh karena memiliki pengaruh yang signifikan. Dalam konteks etnopedagogi, pola pengasuhan dan strategi pendidikan yang dikembangkan oleh perantau Minang di kota Surabaya seyogyanya memperhatikan aspek-aspek kearifan lokal budaya Minang. Sarbaini (2015:3), dengan mengutip Alwasilah et al. (2009), menyatakan bahwa pada prinsipnya etnopedagogi menaruh perhatian khusus terhadap local genius dan local wisdom dengan mengungkapkan nilai-nilai budaya setempat. Bagi masyarakat Minang, falsafah budaya "dimana bumi dipijak, di situ langaik dijunjuang", sangat berpengaruh secara signifikan terhadap pola-pola pengasuhan serta strategi pendidikan yang harus diterapkan. Nilai-nilai kearifan lokal yang lain, seperti cerita-cerita, legenda-legenda, dongeng-dongeng tradisional mengandung nilai-nilai kearifan local Minangkabau dapat pula mewarnai pembentukan karakter atau kepribadian anak (Eliza (2017:162).

Kearifan nilai-nilai budaya lokal (local wisdom atau local genius) menurut Ayatrohaedi (1986), sebagaimana dikutip oleh Vebrianto (2017: 85), telah teruji kemampuannya untuk bertahan sampai sekarang atau sepanjang masa. Alasan-alasannya adalah: (a) mampu bertahan terhadap budaya luar; (b) memiliki kemampuan mengakomodasi unsur-unsur budaya luar; (c) mempunyai kemampuan mengintegrasikan unsur budaya luar ke dalam budaya asli; (d) mempunyai kemampuan mengendalikan; dan (e) mampu memberi arah perkembangan budaya.

Zuriah (2014:176), menjelaskan bahwa untuk mewujudkan pendidikan berbasis etnopedagogi haruslah mengeksplorasi dan mengungkap kembali nilai-nilai kearifan lokal sebagai sumber inovasi dalam bidang pendidikan serta melakukan pemberdayaan melalui adaptasi pengetahuan lokal, termasuk reinterpretasi nilai-nilai kearifan lokal, dan revitalisasinya sesuai dengan kondisi kontemporer. Alwasilah (2008 dan 2009) memandang bahwa pengetahuan atau kearifan lokal (local knowledge, local wisdom) dalam etnopedagogi sebagai sumber inovasi dan keterampilan yang dapat diberdayakan demi kesejahteraan masyarakat. Kearifan lokal adalah koleksi fakta, konsep, kepercayaan, dan persepsi masyarakat ihwal dunia sekitar. Ini mencakup cara mengamati dan mengukur alam sekitar, menyelesaikan masalah, dan memvalidasi informasi. Singkatnya, kearifan lokal adalah proses bagaimana pengetahuan dihasilkan, disimpan, diterapkan, dikelola, dan diwariskan.

Masalah pnelitian ini adalah: bagaimana penerapan nilai-nilai Kearifan Lokal Budaya Minang “dima bumi dipijak, disitu langit dijunjung” dalam Konteks Etnopedagogi oleh Perantau 
Minang di Kota Surabaya? Adapun tujuan peneliytian: untuk memhami bagaimana penerapan nilai budaya Kearifan Lokal Budaya Minang “dima bumi dipijak, disitu langit dijunjung” dalam Konteks Etnopedagogi oleh Perantau Minang di Kota Surabaya.

\section{METODE}

Jenis penelitian adalah kualitatif. Pertimbangannya, semua data-data yang dibutuhkan memerlukan penjabaran dan penjelasan secara kualitaif, menggunakan pemikiran deduktif yaitu peneliti harus menggunakan keterampilan-keterampilan berpikir di sepanjang proses penelitian berlangsung (Creswell, 2015:59). Pendekatan yang digunakan adalah etnografi, bertujuan untuk membuat deskripsi secara sistematis, aktual, dan akurat mengenai fakta dan sifat fenomena yang diteliti (DT Kependidikan: 2008: 39). Untuk memahaminya harus dilakukan melalui beberapa kali pengamatan serta wawancara mendalam (depth interviews). Lokasi penelitian di wilayah Kota Surabaya. Pelaksanaan di lapangan selama tiga bulan dimulai Agustus sampai Oktober 2018. Tehnik analisis data mengacu pada pendapat Wolcott (1994:36) dan Miles dan Huberman (1992).

\section{HASIL DAN PEMBAHASAN}

\section{Penerapan Falsafah Budaya Minang}

Falsafah budaya Minang “dima bumi dipijak, disitu langik dijunjuang” inilah yang harus dipegang teguh sebagai dasar para perantau Minang bersosialisasi dan beradaptasi dengan semua orang di lingkungan kehidupan perantauan. Falsafah ini selalu diikuti dengan pepatah" elok-elok manyubarang, jan sampai titian patah; elok di rantau urang, jan sampai babuek salah" (berbuat baiklah di negeri orang jangan sampai berbuat salah). Pepatah lain adalah: "baso-basi, malu jo sopan" dan "tenggang raso" (Demina, 2016:8). Dengan beretika yang baik, orang Minang sangat yakin akan tetap dikenang selamanya walaupun orang tersebut sudah meninggal dunia. Selanjutnya, Tidak hanya itu, masih banyak lagi pepatah yang mengandung nilai budaya Minang lainnya yang semuanya bermakna sebagai etika sosial dan harus dipegang teguh dan dipatuhi dalam setiap kehidupan dan pergaulan sosial. Semua informan mengaku mewujudkan makna 
falsafah budaya "dima bumi dipijak, disitu langik dijunjuang” selama hidup di kota Surabaya. Konsistensi menerapkan falsafah budaya ini antara lain menimbulkan sikap dan perilaku saling menghormati (toleransi), saling menghargai, dan inklusif.

\section{Lebih suka berdagang daripada sebagai pegawai.}

Kato (Kato, 2005) pernah mengadakan penelitian tentang orientasi pekerjaan orang Jawa dengan orang Minangkabau. Kenapa orang Jawa lebih cenderung berkerja dengan kerajaan sementara orang Minangkabau lebih cenderung berniaga. Birokrasi Indonesia telah berkembang pada kadar yang membimbangkan sejak kemerdekaan tanpa perkembangan yang seimbang dalam bidang industri dan perdagangan. Sebahagian daripada masalahnya adalah "semua orang" dengan sedikit pengecualian mau menjadi pegawai (sebagai pejabat). Orang Minangkabau adalah antara sebilangan kecil pengecualian itu. Menurut tafsiran mereka sendiri, orang Minangkabau terlalu bebas dan berdikari, perwatakan mereka tidak cukup patuh untuk bekerja dalam birokrasi. Bahkan, Kato (2005:9) berpandangan bahwa orang Minangkabau seolah-olah memainkan peranan sebagai para pejuang yang melahirkan usahawan-usahawan pribumi dalam proses pemodernan Indonesia.

Yahya, informan kelahiran Padang Pariaman tahun 1970, mengatakan bahwa dia sejak awal tidak pernah bercita-cita menjadi pegawai negeri atau karyawan (buruh) suatu perusahaan. Itulah sebabnya, Yahya sejak awal merantau (1998) ke kota Surabaya usianya sudah menginjak 28 tahun. Pada saat itu, dia langsung merintis usaha bisnis kuliner (rumah makan Padang). Ketika penelitian ini dialakukan berarti dia telah 20 tahun menekuni usahanya itu. Ketika berada di kampungnya, dia belum punya usaha, pekerjaannya hanya menjaga harta pusaka saudara perempuannya. Sesuai dengan aturan dalam budaya matrilineal dia tidak berhak memiliknya. Padahal, di usia sudah lebih dari 20 tahun dia mengaku harus berumahtangga, mempunyai isteri dan anak. "Dengan apa saya harus menghidupi mereka?”, katanya.

Sebagaimana perantau Minang yang lain, tujuan utama Yahya merantau untuk meningkatkan taraf hidup dengan niat untuk berdagang, yaitu di bidang usaha usaha kuliner atau rumah makan Padang. Dengan modal pas-pasan, sekitar Rp 15 juta memulai membuka rumah makan (warung makan) Padang. Sampai akhirnya, Yahya mampu meraih pendapatan sekitar Rp 2.500.00, - perhari. 
Ketika ditanyakan mengapa memilih berusaha berdagang di bidang rumah makan bukan bekerja sebagai pegawai (negeri/swasta), Yahya dengan jujur mengatakan bahwa dari segi pendapatan berdagang bisa memperoleh uang setiap hari, sedangkan pegawai baru memperoleh uang setiap bulan. Bagi Yahya, uang yang diperoleh setiap hari bisa segera diputar sehingga alur keuntungan menjadi lebih cepat. Pemikiran yang sangat rasional secara ekonomi ini merupakan suatu kecerdasan orang Minang dalam hal mencari nafkah.

Yahya mengatakan bahwa dirinya, begitu pula orang Minang yang lain, tidak suka menjadi pekerja atau buruh yang setiap hari selalu diperintah dan diatur-atur oleh majikan sehingga tidak memiliki kebebasan bertindak dalam mencari nafkah. Dengan berdagang Yahya mengaku tidak terikat oleh aturan-aturan yang dibuat boleh orang lain (majikan) sebab dia sendirilah yang bertindak sebagai majikan. Itu sebabnya, orang Minang menganggap menjadi pegawai atau buruh sama artinya dengan menjadi "kuli" dengan upah yang tidak seberapa yang baru diterima setelah sebulan bekerja. Makan gaji atau upah dan memburuh bukanlah budaya yang disanjung oleh masyarakat Minang yang merantau.

Kenyataan di atas seakan mempertegas hasil penelitian yang menyatakan bahwa kebanyakan orang Minangkabau di rantau lebih suka manggaleh (berdagang) daripada berkerja makan gaji atau dengan kerajaan (lihat: Naim, 1994; Bungo dan Hussin, 201:121; Septian, 2017:69). Hal ini karena, pertama, secara struktural hidup makan gaji sangat terikat dengan lokasi tempat tinggal dan dengan birokrasi pekerjaan itu sendiri terutama bila dibandingkan dengan pekerjaan lainnya seperti berdagang dan bertukang sendiri. Keterikatan ini menyebabkan mobilitas mereka sangat terbatas sedangkan kebebasan individu merupakan ukuran utama dalam pemilihan pekerjaan di rantau.

\section{Modifikasi rasa atau selera.}

Orang Minang sudah dikenal lihai dan cerdas dalam hal menyiasati rasa/selera makanan sehingga cocok dan sesuai dengan rasa/selera setempat (Hastuti, 2015:820). Tepatnya Hastuti, mengatakan: Minang ethnic is very famous for his capability in the field of business and commerce. Their capabilities as entrepreneurs (entrepreneurs) are likely influenced by the migrating tradition. Entrepreneurs from ethnic Minang are most known in the culinary business. 
Para perantau Minang, yang menjadi informan dalam penelitian ini, khususnya yang menekuni bidang usaha kuliner (rumah makan Padang), mengakuinya. Kecerdasan tersebut pada dasarnya merupakan salah saatu bentuk perwujudan dari falsafah budaya "dima bumi dipijak, disitu langik dijunjuang." Dengan bekal kecerdasan ini mereka telah mampu menyesuaikan masakan Padang yang di daerah asalnya memiliki rasa (agak) asin dan sangat pedas, kemudian disiati menjadi agak manis dan tidak terlalu pedas ketika mereka membuka rumah makan Padang di di kota Surabaya. Oleh karenanya, usaha kulinernya berhasil diminati oleh banyak orang. Bahkan, masakan Padang dikenal juga sampai ke manca negara.

\section{Berhasil menduduki jabatan truktural puncak.}

Meskipun pada umumnya perantau Minang menekuni usaha kuliner dengan membuka Rumah Makan Padang, namun ada pula yang berprofesi sebagai pendidik. Irham, salah seorang informan yang berpendidikan S-3 dan berhasil menduduki jabatan puncak akademik di auatu perguruan tinggi negeri di kota Surabaya. Ketika dia lulus SLTA sudah berkeinginan untuk merantau sambil melanjutkan ke jenjang pendidikan lebih tinggi. Pada saat itu, mamaknya sebenarnya menghendaki dirinya tidak merantau ke Jawa dan menetap di kampung. Sebabnya, Irham diharapkan kelak bisa menjadi mamak juga dan sekaligus datuak.

Selama merantau, Irham mengakui bahwa falsafah budaya "dima bumi dipijak, disitu langik dijunjuang” benar-benar diterapkan. Irham menceritakan pengalamannya bahwa sejak menjadi tenaga pengajar selalu menempatkan diri sesuai dengan lingkungan kerjanya, dengan semangat profesialisme. Artinya, dia tidak pernah menunjukkan sikap dan perilaku "mengambil muka" atau sikap dan perilaku lain semacam itu tapi menunjukkan prestasi akademik. Dengan berpedoman pada falsafah budaya Minang “dima bumi dipijak, disitu langik dijunjuang” pribadi Irham disenangi oleh semua koleganya. Meskipun terjadi suksesi di lingkungan kerjanya, Irham selalu mendapat perhatian khusus dari pimpinannya yang baru. Hal ini juga berpengaruh terhadap kariernya yang terus berkembang hingga ke tingkat struktur jabatan yang tertinggi.

\section{Bangga mampu berbahasa Jawa.}

Dua orang informan, Bakirafdi dan Daus, sama-sama berhasil meraih pendidikan pascarajana sesuai dengan cita-cita ketika di SLTA. Di kota Surabaya, Bakirafdi rupaya tertarik pada dunia jurnalistik, sehingga selama sekitar 40 tahun tetap menekuni profesi sebagai wartawan 
dan kariernya menanjak sebagai pemimpin redaksi dari suatu media massa terkenal hingga memasuki masa pensiun lima tahun yang lalu. Adapun Daus, di kota Surabaya, berhasil meraih pendidikan Strata-1 dengan mengambil jurusaan ekonomi (management) di suatu perguruan tinggi swasta. Alasannya, sebagai bekal mengelola restorannya.

Kedua informan ini nampak fasih berbahasa Jawa. Bakirafdi justru merasa nampak bangga bebahasa Jawa terlihat ketika wawancara dilakukan selalu diselingi dengan bahasa Jawa. Setiap mengucapkan kata-kata bahasa Jawa raut mukanya terlihat jelas terpancar kebanggaan, meskipun logat bahasa Jawanya tidak seperti logatorang Jawa. Ketika ditanyakan sudah berapa lama belajar bahasa Jawa, dijawabnya sekitar 30-an tahun. Belajar bahasa Jawa dengan cara "sambil lalu" terutama ketika meliput peristiwa-peristiwa yang layak untuk dimuat di surat kabar yang dia asuh. Dengan penuh semangat mereka terus belajar dan belajar. Meskipun mengahadapi banyak kendala, namun tidak menyrutkan untukterus belajar bahasa Jawa. Pepatah: baraja ka na manang, mancontoh ka nan sudah. Pepatah ini yang intinya harus terus belajar, pantang menyerah menjadi pegangan hidupnya. Akhirnya dia mampu mengatasi kendala bahasa dalam beradaptasi dengan masyarakat Surabaya. Namun demikian, Bakirafdi tetap tidak melupakan bahasa ibu, yaitu bahasa Minang. Ketika wawancara berlangsung, dia lebih sering menggunakan bahasa Minang, sehingga keakraban dalam wawancara itu sangat terasa dan suasana menjadi sangat cair, tidak kaku, dan penuh dengan rasa kekeluargaan.

\section{Strategi Pola Pengasuhan dan Pendidikan Anak-anak.}

Meskipun kepribadian seseorang (anak) dapat dibentuk melalui pendidikan sebagaimana telah disebutkan pada pendahuluan di atas, namun proses pengasuhan serta pendidikan pada umumnya dan khususnya pengasuhan serta pendidikan pada anak seharusnya tidak ditempatkan dalam ruang hampa sosial-budaya. Artinya, dalam proses tersebut dimensi sosial-budaya masyarakatnya berupa nilai-nilai yang masih berlaku harus diperhatikan oleh karena memiliki pengaruh yang signifikan. Dalam masyarakat Minang yang memiliki falsafah budaya "dimana bumi dipijak, di situ langaik dijunjuang", sudah barang tentu falsafah budaya ini berpengaruh secara signifikan terhadap pola-pola pengasuhan serta strategi pendidikan yang harus diterapkan. Salah satu hasil penelitian lapangan seperti yang telah dilakukan oleh Eliza (2017:162) menyebutkan bahwa cerita-cerita, legenda-legenda, dongeng-dongeng tradisional mengandung 
nilai-nilai kearifan local Minangkabau sehingga dapat mewarnai pembentukan karakter atau kepribadian anak.

\section{Mengganti peran dan fungsi mamak.}

Sebagai masyarakat dengan system kekerabatan berdasarkan garis ibu (milineal kinship system) para perantau Minang di kota Surabaya tidak sepenuhnya dapat menarapkan kaidah-kaidah yang berlaku pada system kekerabatan ini dalam hal pengasuhan dan pendidikan anak. Secara kultural peranan dan fungsi ini terutama dalam hal mengasuh, mendidik anak, membimbing, dan semacamnya menjadi tanggung jawab mamak (kakak kandung laki-laki dari garus keturunan inu) kepada kemenakannya (anak-anak dari saudara kandung dalam garis ketuurunan ibu). Orangtua laki-laki atau bapak adalah 'ayah biologis' dari anak-anaknya, sedangkan 'ayah sosial' dari anakanak tersebut adalah ninik mamak-nya. Di bidang ekonomi, pendidikan, pewarisan kedudukan politik, keamanan, dan lain-lain, tanggung jawab dan wewenang berada di tangan ninik mamak. Apabila anggota kelompok domestik, atau kelompok rumah gadang menderita kurang makan dan pakaian, ninik mamak merekalah yang disalahkan. Apabila seorang anak terlihat nakal atau melanggar norma masyarakat, mamak-nyalah yang dianggap kurang pandai mendidik kamanakan. Apabila seorang anak berada dalam bahaya, maka mamak pulalah yang bersabung nyawa. Kedudukan datuk sebagai 'direktur utama' kelompok domestik diturunkan kepada kamanakan. Kedudukan mamak sebagai 'manager' kelompok diturunkan kepada kamanakan, dan demikianlah seterusnya (Marzali, 2000:11).

Betapa pentingnya peranan dan fungsi mamak dalam pengasuhan, memebimbing, dan mendidik kemenakan, sementara para kemenakannya berada di rantau bersama orangtuanya. Peran dan fungsi informan sebagai orangtua (ayah dan ibu) menjadi penting untuk mengisi peran dan fungsi mamak yang tidak optimal melaksanakan peran dan fungsinya. Hal ini diakui oleh semua informan. Artinya, para orangtua yang kini sedang berada di rantau berkewajiban mengasuh dan mendidik anak-anak mereka. Khusus untuk urusan yang berkaitan dengan pewarisan harta pusaka dan menentukan calon jodoh bagi anak-anak mereka, para orangtua harus berkonsultasi dengan mamak di kampung.

Sebagaimana telah diatur secara kultural, harta pusaka tidak boleh dijual apa pun alasanya melainkan menjadi hak milik anak-anak perempuan, dan untuk selanjutnya harus diwariskan pula 
kepada anak-nanak perempuan pada generasi berikutnya. Dalam konteks ini, fungsi dan peran ninik mamak terhadap kemenakan-kemenakan perempuan sangat penting dan menentukan. Keberlangsungan garis keturunan sesuai dengan marga atau suku sangat ditentukan oleh para menantu tersebut. Oleh karena itu, peran dan fungsi ninik mamak tidak boleh diabaikan, bahkan mutlak harus dilibatkan secara optimal. Berbeda dengan anak perempuan, konsultasi dan bimbingan terhadap kemenakan anak laki-laki, peran dan fungsi ninik mamak hanya meliputi membimbing menumbuhkan kemampuanya agar kelak mampu memelihara harta pusaka serta mempersiapkan untuk dapat mewarisi fungsi ninik mamak sebagai pemimpin dalam lingkungannya, baik dalam lingkungan rumah maupun dalam lingkungan suku (Marzali, 2000; Naim, 1994; dan Kato, 2005). Dalam hal urusan ini, konsultasi dengan ninik mamak tidak mutlak, namun tetap penting.

Dalam hal urusan penanaman nilai-nilai budaya Minang untuk membentuk karakter dan budi pekerti yang baik bagi anak-anak mereka tidak harus berkonsultasi dengan mamak di kampung. Begitu pula tentang menentukan pilihan jenis pendidikan serta pilihan jenis pekerjaan, para orangtua berperan serta berfungsi secara dominan. Namun, jika ada hal-hal amat penting dan serius yang harus dibicarakan dan memerlukan pertimbangan dari mamak, khususnya menyangkut pembagian harta pusaka, para orangtua tetap harus berkonsultasi dengan mamak di kampung.

Sebagaimana diceritakan oleh Irham dan Bakirafdi, ketika mereka harus menentukan pilihan calon-calon menantu. Anak laki-laki Irham dan anak perempuan Bakirafdi kebetulan samasama akan memperoleh jodoh bukan orang Minang. Kondisi ini memerlukan pertimbangan yang mendalam dari para mamak serta kerabat lainnya yang ada di kampung. Baik Irham maupun Bakirafdi selain memanfaatkan hubungan telpon pintar, memerlukan pulang kampung bersama anak-anak mereka yang akan mendapatkan jodoh itu. Beberapa aspek penting harus dipertimbangkan dan dibicarakan bersama dengan sangat rinci dan mendalam, misalnya tentang asal keturunan, pendidikan, budi pekerti, dan mungkin juga kepribadian calon menantu. Artinya, meskipun mamak memiliki tanggung jawab sangat besar terhadap keponakan-keponakan itu, pertimbangan dari pihak orangtua serta kemenakan sendiri serta kerabat tetap diperhatikan. Masalah pernikahan akan menentukan kualitas dan keberlangsungan kekerabatan pada generasi beikutnya. Dalam konteks ini, system kekerabatan bardasarkan garis ibu (matrilineal kinship 
system) tidak diberlakukan secara kaku dan ketat. Dimensi kebersamaan dalam kesatuan kekerabatan, atau semangat demokratisasi dalam hubungan kekerabatan tetap mendapatkan ruang.

Setiap kali para perantau Minang di kota Surabaya pulang kampung, saat-saat seperti ini dimanfaatkan pula untuk menjalin hubungan secara langsung antara mereka dan anak-anak dengan mamak. Dengan demikian, fungsi dan peran mamak yang terkendala oleh faktor lokalitas atau geografis tidak sepenuhnya bisa dihilangkan, termasuk hubungan silaturahim antara anak-anak mereka dengan para mamak serta kerabat lainnya tetap terpelihara dengan baik.

\section{Contah tauladan sikap dan perilaku.}

Dalam hal pendidikan serta penanaman nilai-nilai budaya Minang untuk membentuk karakter dan budi pekerti luhur anak-anak mereka di rantau, diakui oleh semua informan bahwa peranan mereka sangat dominan. Meskipun pembelajaran selalu dilakukan secara verbal (lisan), memberikan contoh perilaku dan tindakan dirasakan sangat penting. Secara verbal, penanaman nilai-nilai budaya Minang biasanya dilakukan tidak secara formal, lebih banyak dengan cara menasehati pada saat anak-anak mereka mengalami masalah kesopanan. Misalnya, ketika anakanak memperilahatkan kurang sopan kepada orang yang usianya lebih tua, para orangtua langsung menasehatinya. Tidak cukup dengan cara itu, para orangtua memperlihatkan sikap, tindakan, dan perilku sopan santun dihadapan anak-anak mereka.

Sebagai contoh, Bakirafdi mengatakan bahwa pepatah dima bumi dipijak disitu langik dijunjuang tidak cukup hanya dihafal oleh anak-anak mereka melainkan harus bisa dimengerti dan dipahami maknanya sehingga bisa diwujudkan menjadi sikap dan tindakan (perilaku) dalam hidup keseharian. Bukti bahwa nilai-nilai budaya ini telah dimengerti dan dipahami oleh anak-anak mereka, Alfian, salah seorang anak dari Azrial, yang masih bersekolah di salah satu SMP di kota Surabaya, ketika diwawancarai ternyata mampu menjelaskan dengan baik makna falsafah budaya dima bumi dipijak disitu langik dijunjuang. Katanya, "ambo di sakolah jo di tampek disiko haruih pandai-pandai bakawan jo mangharagoi kawan supayo indak dapek masalah nantinyo" (saya di sekolah dan di tempat ini harus pandai-pandai bergaul dengan teman agar tidak timbul masalah nantinya). Dengan sikap dan perilaku tersebut, Alfian, mengakui bahwa selama ini dia memiliki banyak teman di sekolahnya dan tidak pernah berkonflik dengan mereka. Hal ini dibenarkan oleh ayah dan ibunya.

\section{Penerapan Nilai-nilai Budaya Minang dalam Konteks Prinsip-prinsip Etnopedagogi.}


Di dalam teori pendidikan yang berdimensi sosio-kultural (etnopedagogi), pada prinsipnya menaruh perhatian khusus terhadap local genius dan local wisdom dengan mengungkapkan nilainilai budaya setempat (Rohman, 2017:35). Lebih daripada itu, penting memahami kaitan yang sangat erat antara proses kebudayaan dengan pendidikan. Keduanya berbicara pada tataran yang sama yaitu nilai-nilai, seperti diungkapkan oleh Sarbaini (2015:3, dengan mengutip Alwasilah et al., 2009),

Dengan demikian, dalam konteks etnopedagogi pola pengasuhan dan strategi pendidikan yang dilakukan oleh perantau Minang di kota Surabaya terhadap anak-anak mereka sangatlah penting memperhatikan aspek-aspek kearifan lokal budaya (local wisdom atau local genius) Minang. Kearifan nilai-nilai budaya lokal, menurut Ayatrohaedi (1986), sebagaimana dikutip oleh Vebrianto (2017: 85), telah teruji kemampuannya untuk bertahan sampai sekarang atau sepanjang masa. Alasan-alasannya adalah: (a) mampu bertahan terhadap budaya luar; (b) memiliki kemampuan mengakomodasi unsur-unsur budaya luar; (c) mempunyai kemampuan mengintegrasikan unsur budaya luar ke dalam budaya asli; (d) mempunyai kemampuan mengendalikan; dan (e) mampu memberi arah perkembangan budaya.

Dengan menanamkan nilai-nilai budaya lokal (local wisdom atau local genius) dalam pendidikan merupakan salah satu cara agar anak-anak tetap menghargai warisan leluhur berupa kepercayaan dan nilai-nilai yang terkadung di dalamnya untuk kemudian diterapkan dalam kehidupan seharihari. Selanjutnya, hal ini akan menumbuhkan sikap cinta terhadap kebudayaan sendiri, dan dalam lingkup lebih luas. secara otomatis menumbuhkan juga rasa cinta terhadap negaranya. Upaya penanaman nilai budaya lokal dapat dilakukan melalui pendidikan formal maupun non-formal termasuk pendidikan yang dilakukan di dalam rumah atau keluarga (Sulistiani, 2017:269).

Beberapa temuan di lapangan tentang nilai-nilai budaya lokal Minang yang diterapkan oleh perantau Minang di kota Surabaya akan dikemukakan dan dibahas berikut ini. Namun, oleh karena semua nilai buadaya lokal atau kearifan lokal pasti dirumuskan dalam bahasa lokal (bahasa ibu) maka sangat penting memahami bahasa lokal sehingga makna-makna yang terkandung di dalam nilai-nilai budaya tersebut bisa dipahami juga sepenuhnya.

\section{Konsistensi menggunakan bahasa lokal.}

Salah satu karakter budaya orang Minang adalah tidak pernah lalai menggunakan bahasa Minang sertiap kali berinteraksi dengan sesama orang Minang di mana pun mereka berada dan 
bertemu. Bahkan, berdasarkan pengamatan penulis, orang Minang sangat tidak suka pada orang Minang yang menggunakan bahasa lain, misalnya bahasa Indonesia, ketika berkomunikasi lisan (berbicara) dengan sesama orang Minang. Orang itu pasti dicemeeh (dicemooh) dengan sindiran yang sangat keras dan menyakitkan yaitu berupa kalimat: “babahaso Minang sajo, kabau”. Artinya, berbahasalah menggunakan bahasa Minang saja, kerbau. Kalimat ini menunjukkan bahwa orang tersebut dianggap sombong, tidak mau mengaku sebagai orang Minang, sehingga tidak pantas lagi disebut sebagai orang Minangkabau, kecuali kerbau.

Untuk merawat dan melestarikan budaya Minang, khususnya bahasanya, Yayasan Gebu Minang, sebagaimana telah disebutkan sebelumnya, pada setiap acara silaturahim selalu mengadakan lomba menyebutkan pepatah-petitih Minang. Setiap peserta harus menyebutkan sebanyak mungkin pepatah-petitih sekaligus menjelaskan arti dan maknanya. Bagi peserta yang mampu menyebutkannya dalam jumlah terbanyak dan dikemukakan dengan bahasa yang baik serta menjelaskan arti dan maknanya dengan baik pula, pihak panitia memberikan hadiah. Menurut Bakirafdi, salah seorang pengurus Yayasan sekaligus sebagai panitia penyelenggara silaturahim ini, menjelaskan bahwa nilai hadiah pada dasarnya tidak terlalu penting, hanya sekadar sebagai penghargaan. Yang sangat penting adalah bagaimana semua peserta silaturahim tidak melupakan arti dan makna pepatah-petitih tersebut sebagai nilai-nilai budaya Minang, dan sekaligus harus mampu mencerna dan menerapkannya dalam kehidupan sehari-hari. Selanjutnya, Bakirafdi menambahkan bahwa mengerti dan memahami nilai-nilai budaya Minang sangat penting demi memelihara dan mempertahankan karakterisik budaya Minang dalam kehidupan sehari-hari, lebihlebih bagi orang Minang yang berada di rantau.

Dalam konteks ini, mengerti dan memahami dengan baik bahasa Minang berarti mengerti dan memahami dengan baik pula makna-makna yang terkandung dalam pepatah-petitih tersebut. Oleh karena pepatah-petitih ini pada dasarnya merupakan kumpulan nilai-nilai kearifan lokal, maka bahasa lokal merupakan media budaya sangat penting utuk menstransfer nilai-nilai kearifan lokal Minang secara turun temurun.

Semua informan dalam penelitian ini mengaku selalu menggunakan bahasa Minang ketika berkomunikasi dengan keluarganya dan/atau dengan sesama orang Minang, meskipun mereka sudah lama berdomisili di kota Surabaya. Seperti dijelaskan oleh Irham, semua anak-anak mereka diwajibkan menggunakan bahasa Minang ketika berkomunikasi dengan dirinya (orangtua) atau ketika berada di rumah. Bahkan salah seorang menantu perempuanya yang kebetulan bukan orang 
Minang, "diwajibkan" mengerti bahasa Minang, walaupun dalam bentuk pasif. Maksudnya, agar keintiman dan kerakraban sebagai suatu keluarga dapat terbentuk dengan baik. Selain itu, katanya: "anak-anak tidak canggung lagi bergaul dengan semua kerabat ketika ada kesempatan pulang ke kampung". Sebagaimana telah disebutkan di muka, mereka sangat menyadari bahwa apabila menggunakan bahasa Indonesia atau bahasa lain ketika berkomunikasi dengan kerabat di kampung pasti akan dicemooh sebagai orang yang sombong dan dianggap bukan lagi sebagai orang Minang, sehingga akan disebut "kerbau".

Selanjutnya, semua informan sudah bisa dipastikan bahwa ketika berkomunikasi dan mengajarkan atau menanamkan nilai-nilai kearifan lokal Minangkabau kepada anak-anak, mereka selalu menggunakan bahasa Minang. Oleh karena anak-anak mereka selalu menggunakan bahasa yang sama, maka makna nilai-nilai kearifan lokal itu menjadi cepat dimengerti dan dipahami dengan baik sehingga terhindar dari kesalah-pahaman. Hal ini membuktikan bahwa peranan bahasa lokal sangat penting dalam kehidupan orang Minang terutama dalam mendidik anak-anak mereka tentang nilai-nilai budaya Minang.

Konsistensi semua orang Minang, termasuk perantau Minang di kota Surabaya, selalu menggunakan bahasa Minang dalam pergaulan sehari-hari merupakan kesadaran memenuhi kewajiban kultural secara bertanggungjawab. Hal ini, kemudian dapat menumbuhkan kesadaran sangat kuat bagi mereka untuk tetap merawat dan mempertahankan eksistensi nilai-nilai budayanya. Tidak menggunakan bahasa Minang dalam berkomunikasi dengan sesama orang Minang sama artinya dengan tidak bertanggungjawab terhadap pelestarian nilai-nilai budaya Minang. Oleh karena itu, sanki sosial yang diharus diterima adalah sangat keras dan sangat menyakitkan, dengan menganggap orang itu kerbau.

Beberapa nilai-nilai budaya atau kearifan lokal Minang yang penting diperhatikan, dimasukkan, dipertahankan, dan diwujudkan dalam prinsip-prinsip etnopedagogi, antara lain adalah:

\section{Dima bumi dipijak, disitu langik dijunjuang.}

Nilai kearifan lokal yang terkandung dalam falsafah budaya ini adalah: sikap dan perilaku saling menghormati (toleransi), saling menghargai, tenggang rasa, dan inklusif. Untuk lebih 
mempertegas makna falsafah budaya ini, selalu diikuti oleh pepatah: elok-elok manyubarang, jan sampai titian patah, elok di rantau urang, jan sampai babuek salah. Pada parinsipnya semua orang Minang harus berhati-hati, menjaga etika sopan santun, jangan sekali-kali menyakiti hati orang ketika di rantau atau dimana saja berada.

Nilai keraifan lokal ini sangat penting diperhatikan oleh karena seiring dengan perkembangan masyarakat yang semakin modern maka egoisme semakin menguat. Hidup berdampingan dengan semangat gotong-royong sudah mulai sirna. Masing-masing individu tidak peduli dengan individu yang lain. Sikap dan perilaku hidup egoisme ini tidaklah cocok dengan nilai-nilai budaya bangsa Indonesia yang prulalis yang menempatkan nilai persatuan pada posisi terpenting.

\section{Karatau madang di hulu, Babuah babungo balun; Marantau Bujang dahulu, Di} rumah baguno balun.

Artinya: "ke rantau madang di hulu, berbuah berbunga belum, merantau bujang dahulu, di rumah berguna belum”. Makna pepatah ini sangat tegas menganjurkan para remaja yang masih dalam proses mencari dan menemukan jati dirinya dan dianggap masih belum berguna di kampungnya karena belum memiliki mata pencaharian sendiri (mandiri) harus merantau keluar dari kampung halaman (Marta, 2014:30). Dengan kata lain, hidup mandiri adalah inti dari nilai keraifan lokal ini.

Dalam perkembangan masyarakat yang sangat kompetitif, kemandirian menjadi modal sosial sangat penting bagi setriap orang untuk survive. Menganggantungkan hidup kepada orang lain, bukan solusi yang cerdas bahkan boleh dikatakan tidak produktif. Cepat atau lambat, akan tergerus oleh arus kompetitisi yang semakin tajam.

\section{Baraja ka na manang, mancontoh ka nan sudah.}

Takuruang nak dilua, taimpik nak diateh.

Dua pepatah meruapakan salah satu pegangan hidup perantau Minang di kota Surabaya. Initinya bermakna pantang menyerah. Sejak kanak-kanak orang Minang sudah dijari dan 
dididik menjadi orang yang tangguh, tahan menghadai segala rintangan hidup. Pepatah pertama mengajarkan, misalnya ketika di perantuan mengalami kendala atau kegagalan, mereka haruslah belajar pada orang yang telah berhasil tentang bagaimana meraih keberhasilannya. Begitu pula penting untuk mencontoh pada orang-orang yang sudah pernah mengalami kegagalan yang sama. Mereka harus belajar mengapa orang juga mengalami kegagalan dan belajar bagaimana mengatasi kegagalan itu. Pepatah kedua, bermakna bahwa meskipun terjepit masalah, orang Minang harus berusaha untuk mengatasinya kemudian bangkit kembali. Dengan semangat pantang menyerah, para perantau Minang dapat survive di mana pun mereka berada.

\section{Adat basandi syarak, syarak basandi kitabullah.}

Makna pepatah ini pada intinya setiap perilaku harus bersandarkan pada nilai-nilai agama. Bagi orang Minangkabau pepatah ini merupakan filosofi adat Minangkabau yang menjadi pedoman dalam kehidupan bermasyarakat. Sudah diketahui secara luas, bahwa orang Minang sangat taat terhadap keyakinan agamanya (Islam). Semua sikap dan perilaku harus berpedoman pada adat istiadat selanjutnya adat-istiadat harus berdasarkan syarak, dan syarak harus berpedoman pada Kitabullah. Proses ketaatan orang Minang pada ajaran Islam sudah dimulai sejak anak-anak masih berusia muda. Merka sudah harus pergi ke surau untuk mengaji (belajar agama Islam). Bahkan, bagi anak laki-laki harus tinggal di surau hingga menginjak usia dewasa sebagai konskuensi system kekerabatan matrilineal (matrilineal kinship system). Itu sebabnya, setiap langkah dan tindakan/perilaku orang Minang di mana pun berada tetap berpedoman pada nilainilai ajaran Islam.

Penanaman nilai-nilai agama sangat penting dan sangat relevan untuk dimasukkan daln prinsip-prinsip etnopedagogi. Sudah menjadi pengetahuan umum, bahwa pengaruh arus globalisasi membuat para remaja abai terhadap ajaran agama. Kehidupan hedonis, pennyalahgunaan narkoba, dan kebebasan seksual seakan sudah menjadi berita sehari-hari.

\section{Mempertahankan bahasa ibu (lokal).}


Sebagaimana telah terbukti dalam penjelasan dan bahasan sebelumnya, orang Minang sangat konsisten dalam menggunakan bahasa ibu (bahasa Minang) dalam segala aspek kehidupannya. Sanksi sosial atas poelanggaran ini sangat berat. Dengan konsistensi ini nilai-nilai budaya lokal Minang tetap terawat dan dipertahankan dengan baik hingga saat ini. Secara kultural, nilai-nilai budaya Minang dapat secara lebih mudah ditransfer secara turun temurun melalui bahasa lokal (bahasa Minangkabau). Selanjutnya, dengan cara ini orang Minang memiliki identitas etnis yang kuat. Dalam konteks etnopedagogi, muatan bahasa lokal sangat penting diperhatikan demi mempermudah mengerti dan memahami nilai-nilai yang terkandung dalam kearifan lokal masyarakat yang bersangkutan.

\section{KESIMPULAN DAN REKOMENDASI}

\section{Kesimpulan}

Berdasarkan hasil dan pembahasan dapat disimpulkan bahwa terdapat lima nilai budaya MInang penting diperhatikan dalam prinsip-prinsip etnopedagogi, yaitu nilai-nilai yang mencerminkan:

Sikap dan perilaku saling menghormati (toleransi), saling menghargai, tenggang rasa, dan inklusif ("Dima bumi dipijak, disitu langik dijunjuang”).

Hidup mandiri, ("Karatau madang di hulu, Babuah babungo balun; Marantau Bujang dahulu, Di rumah baguno balun”).

Sikap dan perilaku pantang menyerah (“Baraja ka na manang, mancontoh ka nan sudah”. Dan “Takuruang nak dilua, taimpik nak diateh”).

Mengutamakan nilai-nilai agama (“Adat basandi syarak, syarak basandi kitabullah”).

\section{Mempertahankan bahasa lokal.}




\section{Rekomendasi}

Oleh karena pendidikan berbasis kearifan lokal (etnopedagogi) adalah suatu proses enkulturasi nilai-nilai budaya yang menjadi landasan dalam cara berkarakter yang harus dilakukan dalam suatu proses yang berkelanjutan, yang realisasinya dilakukan melalui pendidikan di lingkungan rumah tangga, pendidikan di masyarakat, dan pendidikan di persekolahan (Sunaria, 2016:53), maka sangat penting merekomendasikan kelima nilai-nilai budaya Minangkabau tersebut dimasukkan sebagai bagian dari materi etnopedagogi dengan cara disesuaikan dengan nilai-nilai budaya setempat***

\section{PUSTAKA ACUAN}

Adler, Patricia A. \& Adler, Peter (1994). "Observational Techniques” dalam

Handbook of Qualitative Research. Edited by Norman K. Denzin and Yvonna S. Lincoln. 377-392.

California: Sage Publications, Inc.

Alwasilah, A. C., Suryadi, K., Tri Karyono, (2009). Etnopedagogi: Landasan Praktek Pendidikan dan Pendidikan Guru. Bandung: Kiblat Buku Utama.

Ayatrohaedi. (1986). Kepribadian Budaya Bangsa (Local Genius). Jakarta: Pustaka Jaya.

Creswell, John W. (2015). Penelitian Kualitatif \& Desain Riset.Yogyakarta:Pustaka Pelajar.

DT Kependidikan, JPD Mutu, Depdiknas. (2008). Pendekatan, Jenis, dan Metode Penelitian Pendidikan. Jakarta: Bib Tex. https://s3.amazonaws.com/academia.edu.documents/45729461/PENELITIAN_PENDIDIKAN.pdf?AWSA ccessKeyId=AKIAIWOWYYGZ2Y53UL3A\&Expires=1539935528\&Signature=98gg6OszGelFuZgwYiU caSXfrfA\%3D\&response-contentdisposition=inline\%3B\%20filename\%3DKompetensi_Penelitian_dan_Pengembangan_0.pdf

Geertz, Clifford. (1973). The Interpretation of Culture. Hammersmith, London: Fontana Press. 
Kato, Tsuyoshi. (2005). Adat Minangkabau dan Merantau dalam Prespektif Sejarah. Jakarta: PT. Penerbitan dan Percetakan Balai Pustaka.

Miles, Matthew B. \& Huberman, A. Michael. (1992). Analisis Data Kualitatif. Diterjemahkan oleh Tjetjep Rohendi Rosidi. Jakarta: Universitas Indonesia.

Naim, Mochtar. (1994). Merantau Pola Migrasi Suku Minangkabau.. Yogyakarta: Gadjah Mada University Press.

Sjarifoedin, Amir. (2014). Minangkabau. Jakarta: PT. Gria Media Prima.

Spradley, James P. (1997). Metode Etnografi. Pengantar: Dr. Amri Marzali, M.A.

Yogyakarta: PT Tiara Wacana.

Wollcot, Harry F. (1994). Transforming Qualitative Data: Description, Analysis, and Interpretation. Thousand Oaks, CA.: Sage Publications, Inc.

Ardi, Havid. (2015). Cross Cultural Communication Awareness in Translation. International Conference on Languages and Arts. pp. 229-234. Padang: UNAND. ejournal.unp.ac.id/index.php/isla/article/download/5293/4178

Bungo, Nelmawarni dan Hussin, Nordin”(2011). Merantau ke Kuala Lumpur: Tradisi merantau dan berdagang masyarakat Minang. GEOGRAFIA Online ${ }^{\mathrm{TM}}$ Malaysian Journal of Society and Space 7. Special Issue: Social and Spatial Challenges of Malaysian Development (116 - 131) @ 2011, ISSN 2180-2491. http://ejournal.ukm.my/gmjss/article/view/19951/6307

Debby, Nia Novinta (2017). Gambaran Peran Mamak dalam Pengasuhan Kemenakan pada Etnis Minangkabau. Diploma thesis, Universitas Andalas. http://scholar.unand.ac.id/30329/2/BAB\%20I.pdf

Demina. (2016). Membumikan Nilai Budaya Lokal dalam Membangun Karakter Bangsa. Jurnal Ta'dib. Volume 16. No. 1. Batusangkar: IAIN Batusangkar. ecampus.iainbatusangkar.ac.id/ojs/index.php/takdib/article/download/242/240

Elfira, Mina. (2018). The Contributions of Minangkabau Women, Establishes Intercultural Marriages, in Creating a "New Identity" of the Minangkabau Diaspora. Proceeding of The Asia Pacific Research in Sosial Humanities. Depok, Indonesia: 7-9 November 2016, pp. 175-180. London, UK: Taylor \& Francis Group. www.oapen.org/download?type=document\&docid=639549\#page=187 
Eliza, Delfi. (2017). Pengembangan Model Pembelajaran Karakter Berbasis

Cerita Tradisional Minangkabau untuk Anak Usia Dini. PEDAGOGI: Jurnal Anak Usia Dini dan Pendidikan Anak Usia Dini. Volume 3 Nomor 3b. pp. 153-163. PG PAUD UMSurabaya. journal.um-urabaya.ac.id/index.php/Pedagogi/article/download/1072/887

Hastuti, P.C., A. Thoyib, E. A. Troena, and M. Setiawan,. (2015). The Minang

Entrepreneur Characteristic, Procedia - Sosial Behavior Science., vol. 211, no. September, pp. 819-826. https://core.ac.uk/download/pdf/82266975.pdf

Marta, Suci. (2014). Konstruksi Makna Budaya Merantau di Kalangan Mahaiswa

Perantau. Jurnal Kajian Komunikasi, Volume 2, No. 1, Juni, hal. 27-43. Bandung: LP3 Fikom Unpad. https://scholar.google.co.id/scholar?hl=id\&as_sdt=0\%2C5\&q=Konstruksi+Makna+Budaya+Merantau+di+ Kalangan+Mahaiswa++Perantau.+\&btnG

Marzali, Amri. (2000). Dapatkah Sistem Matrilineal Bertahan Hidup di Kota Metropolitan? dalam Jurnal Antropologi Indonesia, Vol. 61. Hal. 1-15. Jakarta: Universitasamir Indonesia. journal.ui.ac.id/index.php/jai/article/viewPDFInterstitial/3379/2663

Rahim, Umar Abdur. (2017). Pesan-pesan Komunikasi Dakwah dalam Petatahpetitih Minang. Jurnal Sosial Budaya (e-ISSN 2407-1684 p-ISSN 1979-2603). Vol. 14, No. 1, Juni. pp. 63 79. Pekanbaru: Universitas Islam Negeri Sultan Syarif Kasim Riau. http://ejournal.uin-suska.ac.id/index.php/SosialBudaya/article/viewFile/4358/2671

Rohman, Miftahur. (2017). Internalisasi Nilai-nilai Sosio-kultural Berbasis Etno-religi di MAN Yogyakarta III. INA-RxIV Papers. Vol. 12, No. 1, Februari. Halaman 31-56. https://osf.io/preprints/inarxiv/suz9b/download?format=pdf

Sarbaini, (2015). Rekonstruksi Nilai-Nilai Baiman, Bauntung, Batuah Milik

Urang Banjar Perspektif Etnopedagogi. Paper in International seminar on Etnopedagogy, November 14. Banjarmasin: Faculty of Teacher Training and Eduation Lambung Mangkurat University. https://www.researchgate.net/publication/312921476.

Somantri, Gumilar R. (2005). Memahami Metode Kualitatif. Jurnal Makara, Sosial humaniora, vol. 9, no. 2, Desember. Halaman: 57-65 http://hubsasia.ui.ac.id/old/index.php/hubsasia/article/viewFile/122/110 
Septian, Haris. 2017. Motif Merantau Dalam Kaba. WACANA ETNIK Jurnal Ilmu Sosial dan Humaniora - Vol 8 No 1 April 2017, (1 - 16), p ISSN 2089-8746, e ISSN 2302-7142. wacanaetnik.fib.unand.ac.id/index.php/wacanaetnik/article/download/64/74

Sulistiani. (2017). Model Pembelajaran Berbasis Budaya Lokal dalam Membentuk Jiwa Profetik-Patriotik Peserta Didik. Proceeding Konfrensi Nasional Kewarganegaraan. November 11. Halaman 268-275. Yogyakarta: Universitas Muhammad Dahlan. http://eprints.uad.ac.id/9791/1/268-275\%20Sulistiani.pdf

Sunaria, Nono Harsono. (2016). Kontribusi Local Wisdom Terhadap Pembentukan Karakter Bangsa. Kontribusi Local Wisdom Terhadap Pembentukan Karakter Bangsa. Proceeding of The International Seminar on Philosophy of Education. Primary Foundation in Strengthening Pedagogy Development in Indonesia Future Generation. Universitas Pendidikan Indonesia, December 10, 2016. Pp. 51-60 ISBN: 978-602-74167-1-0 http://jurnal.unma.ac.id/index.php/RBJ/article/viewFile/782/738\#page=59

Thaher, Asri, (2006). Sistem Pewarisan Kekerabatan Matrilineal dan Perkembangannya di Kecamatan Banu Hampu Pemerintahan Kota Agam Propinsi Sumatera Barat. Tesis, (tidak dipublikasikan). Semarang: Program Studi Magister Kenotariatan Universitas Diponegoro Semarang. http://eprints.undip.ac.id/15137/1/asri thaher_b4b_004_075.pdf

Usmarni, Lusi dan Rinaldi. (2014). Perbedaan Keterlibatan Ayah dalam Pengasuhan Anak pada Etnis Minang Ditinjau dari Tingkat Pendapatan. Jurnal RAP UNP, Vol. 5 No. 1, Mei 2014. Hal. 43-52. Padang: Universitas Negeri Padang. ejournal.unp.ac.id/index.php/psikologi/article/download/6639/5198

Vebrianto, Rian \& Zarkasih. (2017). Education of Local Wisdom to Prevent Forest Fires in Riau Province: challenges, potentials, and solutions. Jurnal Sosial Budaya, Vol. 14, No. 1, Juni. Hal. 80a-98. Pekanbaru: UIN Sultan Syarif Kasim (Suska), Riau. http://ejournal.uin-suska.ac.id/index.php/SosialBudaya/article/view/4359

Zuriah, Nurul. (2014). Analisis Teoritik tentang Etnopedagogi Pendidikan Kewarganegaraan sebagai Wahana Pendidikan Budaya dan Karakter Bangsa di Perguruan Tinggi. SOSIOHUMANIKA: Jurnal Pendidikan Sains Sosial dan Kemanusiaan, Vol.7(2) November, pp.175-188. Bandung, Indonesia: Minda Masagi Press, UNHAS Makassar, and UNIPA Surabaya, ISSN 1979-0112. Available online also at: http://www.sosiohumanika-jpssk.com/index.php?lang=en\&p=journal\&act =viewjurnal2\&id=152\&postact=detail 
